Пащук Лідія Віталіївна кандидат економічних наук, доцент кафедри міжнародної економіки маркетингу, Київський національний університет імені Тараса Шевченка, вул. Васильківська 90а, ауд.602, м. Київ, 03022, тел.: (044) 257-92-91, e-mail: lidia_paschuk@yahoo.com, https://orcid.org/0000-0003-1184-1545

Середа Валентина Іванівна кандидат економічних наук, доцент, Київський національний університет імені тараса Шевченка, вул. Васильківська, 90-а, м. Київ, 03022, тел.: (044) 257-92-91, e-mail: valentinasereda10@gmail.com, https://orcid.org/0000-0002-7697-4704

\title{
СИСТЕМНИЙ ПІДХІД ДО ПОСИЛЕННЯ КОНКУРЕНТОСПРОМОЖНОСТІ МАЛИХ І СЕРЕДНІХ ПІДПРИЕМСТВ НА МІЖНАРОДНИХ РИНКАХ
}

Анотація. У статті проведено дослідження експортних можливостей малих i середніх підприємств. Незважаючи на заходи держави стосовно підтримки експорту малого та середнього бізнесу, ці підприємства забезпечують менше $30 \%$ експорту. Спостерігається стагнація реалізації експортного потенціалу МСП, падіння експортності малих та середніх фірм, зменшення частки МСП, що експортують.

Посилення експортного потенціалу МСП базується на їхній конкурентоспроможності, для посилення якої запропоновано заходи як в контексті розвитку територій (міст), так і через механізми підвищення ефективності експортної діяльності.

На основі узагальнення міжнародного та вітчизняного досвіду в межах проекту ПРОМІС запропоновано авторську методику розробки програми посилення конкурентоспроможності малих і середніх підприємств 3 огляду на поточний стан галузі, пріоритетних напрямків розвитку регіону або області, цілей на поточні або майбутні періоди та існуючі можливості. Заслуговують уваги пропозиції застосування бенчмаркінгу, що дає змогу визначити оптимальні визначено покроковий план дій з розробки програми через визначення сильних та слабких сторін МСП міста, виявлення галузевих пріоритетів та розробка рекомендації щодо їхнього розвитку із участю стейкхолдерів.

На національному рівні в Україні реалізується низка проектів за підтримки іноземних донорів, спрямованих на розвиток як в цілому МСП, так і їхнього експортного потенціалу - Ініціатива $\mathrm{CC}$ «EU4Business», Проект FORBIZ, проекти Western NIS Enterprise Fund, Центру зі сприяння імпорту з країн, що розвиваються (Kindom of the Netherland), Канадсько-Український 
проект підтримки торгівлі та інвестицій (CUTIS), Enterorise Europe Network (формування мережі підприємств-партнерів, доступ до інформації, наукового співробітництва, інноваційної підтримки), Agritrade Ukraine (надання консультацій щодо процедур експорту до СС, проведення тренінгів) тощо.

Проте існує низка чинників, які перешкоджають розвитку МСП: низький рівень довіри в суспільстві; слабке верховенство права; політична та економічна нестабільність, лобі великого бізнесу, умови діяльності, що погіршуються.

Ключові слова: підприємництво, експорт малих і середніх підприємств, конкурентоспроможність, бенчмаркінг, стратегія.

Pashchuk Lidiia Vitaliivna Candidate of Economic Sciences, Associate Professor of the Department of International Marketing Economics, Taras Shevchenko National University of Kyiv, Vasylkivska St. 90a, room 602, Kyiv, 03022, tel.: (044) 257-92-91, e-mail: lidia_paschuk@yahoo.com, https://orcid.org/0000-0003-1184-1545

Sereda Valentyna Ivanivna Candidate of Economic Sciences, Associate Professor, Taras Shevchenko National University of Kyiv, Vasylkivska St., 90-a, Kyiv, 03022, tel.: (044) 257-92-91, e-mail: valentinasereda10@gmail.com, https://orcid.org/0000-0002-7697-4704

\section{A SYSTEMATIC APPROACH TO STRENGTHENING THE COMPETITIVENESS OF SMALL AND MEDIUM ENTERPRISES IN INTERNATIONAL MARKETS}

Abstract. The article examines the export potential of small and medium enterprises. Despite government measures to support the export performance of small and medium enterprises, they provide less than $30 \%$ of exports. There is a stagnation in the realization of SMEs' export potential, as well as a decline in exports of small and medium enterprises and in the share of exporting SMEs.

Strengthening the export potential of SMEs is based on their competitiveness. To increase it, measures both connected with the development of territories (cities) and through mechanisms to increase the efficiency of export activities are proposed.

Having generalized the international and domestic experience within the PROMIS project, the author's technique of carrying out the analysis is offered. It takes into account strengthening the competitiveness of small and medium enterprises with regard to the current state of the industry, the priority areas of a region's development, current or future goals, and existing opportunities. Noteworthy are the proposals for the use of benchmarking, which allows to determine the optimal step-by-step action plan for program development by identifying the strengths and weaknesses of SMEs in the city, discussing sectoral priorities and developing recommendations with stakeholders. 
At the national level, Ukraine is implementing a number of projects with the support of foreign donors aimed at developing both SMEs in general and their export potential. They are the EU Initiative "EU4Business", the FORBIZ Project, Western NIS Enterprise Fund projects, the Center for Import Promotion from (Kindom of the Netherland), Canadian-Ukrainian Trade and Investment Support Project (CUTIS), Enterorise Europe Network (forming a network of partner companies, access to information, scientific cooperation, innovation support), Agritrade Ukraine (providing advice on export procedures in EU, trainings), etc.

However, there are a number of factors that hinder the development of SMEs: low level of trust in society; weak rule of law; political and economic instability, big business lobbying, and deteriorating working conditions.

Keywords: entrepreneurship, small and medium enterprises export, competitiveness, benchmarking, strategy.

Постановка проблеми. Українська економіка має високу залежність від зовнішньоторговельної діяльності. I левову частку експортно-імпортних операцій здійснюють великі фірми. Проте у сучасній Україні понад 99\% суб'єктів підприємницької діяльності представляють мале i середнє підприємництво (МСП), які створюють понад $80 \%$ робочих місць та мають значний експортний потенціал [1]. Більше того, дослідження рівня розвитку будь-якої країни демонструє, що важливим фактором у вирішенні іiі внутрішніх проблем є розвиток підприємницької діяльності і особливо малого та середнього бізнесу.

Незважаючи на значний внесок МСП в економіку України рівень довіри до підприємців в українському суспільстві залишається на досить низькому рівні. Рівень довіри до підприємств майже не змінився і ледь сягає 50\% з 1994 року [2].

Після підписання у 2014 році Угоди про асоціацію між Україною, $з$ однієї сторони, та Свропейським Союзом, Свропейським Співтовариством з атомної енергії i їхніми державами-членами, 3 іншої сторони, в нашій країні розпочались активні заходи з розвитку підприємництва, коли державна та місцева влада залучає широкі групи стейкхолдерів до процесів формування стратегій розвитку МСП взагалі та стратегій конкурентоспроможності зокрема. Але в зовнішньоторговельний сфері експортні можливості МСП використовуються слабко, що свідчить про відносно низький рівень конкурентоспроможності українських МСП на міжнародних ринках.

Питання підтримки малого і середнього бізнесу знаходяться як у спектрі уваги країн ОЕСР так і уряду України. Міжнародна діяльність МСП не тільки пов'язана із експортом, але передбачає також пряме іноземне інвестування, забезпечення доступу до новітніх технологій, участь у міжнародному поділі 
праці та кооперації. Але всі ці аспекти тісно безпосередньо пов'язані із посиленням конкурентоспроможності МСП в національній економіці.

Аналіз останніх досліджень i публікацій. Питання конкурентоспроможності висвітлюються широким колом як українських, так і зарубіжних публікацій в економічній літературі. Останнім часом все більше вчених досліджує питання оцінки рівня конкурентоспроможності підприємств та надає рекомендації щодо його підвищення у своїх дослідженнях. Питанням розвитку МСП присвятили дослідження такі вчені, як А.Черняк, Е.Гогу, С.Лачієвич, М.Мрва, М.Мурешан, Х.Роча, К.Шимізу, П.Стахова, М.Стефанський, Г.Ткачук та ін. Їхні роботи присвячені проблемам створення сприятливого клімату для розвитку МСП, конкурентоспроможності МСП, основним напрямкам державної підтримки МСП в Свропейському Союзі, стратегії розвитку малого та середнього бізнесу в Україні тощо.

Питанням розвитку та реалізації експортного потенціалу МСП присвятили роботи Бураковський I., Когут А., Крініцин О., Панцир С., Покришка Д., Сологуб І. [3] та ін.

Незважаючи на існування значної кількості наукових праць на сьогодні, не існує єдиного чіткого алгоритму підвищення конкурентоспроможності та застосування алгоритму для українських МСП. Крім того, посилення глобальних трендів, з одного боку, та зовнішніх шоків - 3 іншого, потребують актуалізації роботи науковців в напрямі аналізу обмежуючих факторів щодо посилення конкурентоспроможності МСП як на національному, так і на міжнародному рівнях. Все вищезазначене обумовлює високу актуальність цієї проблеми.

Мета статті полягає у визначення стану експортної діяльності МСП, дослідженні проблем виходу українських МСП на зовнішні ринки та розробка рекомендацій щодо розвитку конкурентоспроможності МСП з урахуванням регіональних особливостей (на основі визначення рівня конкурентоспроможності МСП окремого міста).

Виклад основного матеріалу. Експорт українських підприємств має сталу динаміку - за 2010-2019 рр. кількість експортуючих підприємств зростала в середньому на 4\% щорічно, збільшувалась частка експортерів у кількості українських підприємств [4]. 32020 р. під виливом covid-19 ця тенденція змінилася в сторону скорочення на фоні зменшення загальної кількості МСП. Проте основну роль у експорті України відіграють великі підприємства, частка яких складає 2/3 і залишається практично без змін 3 2015 р. (табл. 1$).$ 
Таблиця 1

Експортна активність малих, середніх та великих підприємства в Україні*

\begin{tabular}{|c|c|c|c|c|c|}
\hline Показники & 2015 & 2016 & 2017 & 2018 & 2019 \\
\hline \multicolumn{6}{|c|}{ Малі підприсмства } \\
\hline $\begin{array}{l}\text { Кількість малих фірм- } \\
\text { експортерів, од. }\end{array}$ & 9375 & 10302 & 10430 & 10944 & 10988 \\
\hline $\begin{array}{l}\text { Частка фірм-експортерів в загальній } \\
\text { кількості малих підприємств, \% }\end{array}$ & 2,8 & 3,5 & 3,2 & 3,2 & 3,0 \\
\hline $\begin{array}{l}\text { Обсяг експорту малих фірм- } \\
\text { експортерів, млн.дол }\end{array}$ & 4658,2 & 4571,3 & 5028,7 & 5775,7 & 6607,7 \\
\hline $\begin{array}{l}\text { Обсяг експорту на одну малу фірму- } \\
\text { експортера, тис.дол }\end{array}$ & 496,9 & 443,7 & 482,1 & 527,8 & 601,4 \\
\hline $\begin{array}{l}\text { Частка експорту малих фірм у } \\
\text { загальному експорті, \% }\end{array}$ & 13,0 & 13,6 & 12,3 & 12,2 & 13,2 \\
\hline $\begin{array}{l}\text { Частка експорту у виробництві } \\
\text { малих фірм, \% }\end{array}$ & 24 & 24 & 16 & 15 & 9 \\
\hline \multicolumn{6}{|c|}{ Середні підприсмства } \\
\hline $\begin{array}{l}\text { Кількість середніх фірм- } \\
\text { експортерів, од. }\end{array}$ & 2897 & 3111 & 3204 & 3197 & 3254 \\
\hline $\begin{array}{l}\text { Частка фірм-експортерів в загальній } \\
\text { кількості середніх підприємств, \% }\end{array}$ & 19,1 & 21,0 & 21,5 & 19,9 & 18,3 \\
\hline $\begin{array}{l}\text { Обсяг експорту середніх фірм- } \\
\text { експортерів, млн.дол }\end{array}$ & 6060,2 & 5721,3 & 6656,9 & 7319,8 & 8179,8 \\
\hline $\begin{array}{l}\text { Обсяг експорту на одну середню } \\
\text { фірму-експортера, тис.дол }\end{array}$ & 2091,9 & 1839,1 & 2077,7 & 2289,6 & 2513,8 \\
\hline $\begin{array}{l}\text { Частка експорту середніх фірм у } \\
\text { загальному експорті, \% }\end{array}$ & 15,9 & 15,7 & 15,4 & 15,5 & 16,3 \\
\hline $\begin{array}{l}\text { Частка експорту у виробництві } \\
\text { середніх фірм, \% }\end{array}$ & 13 & 10 & 9 & 9 & 9 \\
\hline \multicolumn{6}{|c|}{ Великі підприсмства } \\
\hline $\begin{array}{l}\text { Кількість великих підприсмств- } \\
\text { експортерів, од. }\end{array}$ & 1245 & 1268 & 1266 & 1257 & 1266 \\
\hline $\begin{array}{l}\text { Обсяг експорту великих фірм- } \\
\text { експортерів, млн. дол. }\end{array}$ & $\begin{array}{l}25815 \\
3\end{array}$ & 24628,3 & 29108,8 & $\begin{array}{c}32537 \\
4\end{array}$ & $\begin{array}{c}33415 \\
, 9\end{array}$ \\
\hline $\begin{array}{l}\text { Обсяг експорту на одну велику } \\
\text { фірму-експортера, тис.дол. }\end{array}$ & 20734 & 19423 & 22992 & 25885 & 26395 \\
\hline $\begin{array}{l}\text { Частка експорту великих фірм у } \\
\text { загальному експорті, \% }\end{array}$ & 67,7 & 67,7 & 67,3 & 68,7 & 66,8 \\
\hline $\begin{array}{l}\text { Частка експорту у виробництві } \\
\text { великих підприємств, \% }\end{array}$ & 48 & 43 & 38 & 37 & 36 \\
\hline
\end{tabular}

* Держкомстат України почав проводити дослідження кількості фірм-експортерів з розподілом на малі, середні і великі підприємства тільки з 2015 р. Дані за 2020 р. будуть оприлюднені у листопаді 2021 р.

Джерело: розраховано авторами на основі [5]

Як ми бачимо 3 табл.1 на малі та середні фірми припадає менше 30\% експорту. 3 наведених даних можна виділити як позитивні, так і негативні тренди, які проявляються паралельно: 
- зростання кількості МСП, що здійснюють експорту діяльність (малих - на 17\%, середніх - на 12\%), супроводжується практично стабільною часткою експорту малих фірм у загальному обсязі експорту (1213\%), що свідчить про відсутність процесів нарощування експортного потенціалу МСП;

- зростання обсягів експорту у розрахунку на 1 фірму (малих - на $41 \%$, середніх - на 20\%) супроводжується падінням рівня експортності фірм ${ }^{1}$. Так, частка експорту у виробленій продукції середніх фірм впала на 39\% (з 13\% до 9\%), а малих підприємств - практично на 2/3 (з 24\% до 9\%). Це свідчить про падіння рівня міжнародної конкурентоспроможності МСП і переорієнтація їхньої діяльності на внутрішній ринок. Це підтверджується також дуже низькою часткою малих підприємств-експортерів у загальній кількості малих підприємств - всього 2,8-3,5\% та падінням 32019 р. частки експортерів серед середніх підприємств.

В контексті необхідності диверсифікації експорту України в напрямку зменшення залежності від експорту сировинної продукції така ситуація виглядає не надто обнадійливою.

Системний підхід до посилання конкурентоспроможності малих i середніх підприємств на міжнародних ринках повинен реалізовуватися в двох напрямках:

- по перше, впроваджувати стратегію конкурентоспроможності МСП на внутрішньому ринку; МСП.

- по друге, розробити стратегію реалізації експортного потенціалу

Перший напрямок може бути реалізований через мультиплікативне забезпечення сталого розвитку МСП в окремо взятих містах.

Проект Федерації Канадських муніципалітетів «Партнерство для розвитку міст» ПРОМІС долучався протягом 2017-2018 року до розробки стратегій конкурентоспроможності МСП у низці міст України, зокрема Вінниці та Івано-Франківську. За Індексом конкурентоспроможності міст (IКM) України, ці міста у 2019-2020 році увійшли до переліку міст з високим IКМ [6], серед яких всього є 6 міст. Для порівняння столиця обіймає двадцять першу позиції $з$ двадцяти чотирьох можливих. Таким чином, можна припустити, що наявність методологічно обгрунтованої Стратегії розвитку конкурентоспроможності МСП є одним із важливих елементів посилення конкурентоспроможності міста в цілому. Модель формування програми посилення конкурентоспроможності МСП, що застосовується проектом ПРОМІС у окремому місті, наведена на рис.1.

${ }^{1}$ Рівень екпортності фірми розраховується як частка експорту у виробництві даної фірми. 
Проведення опитування МСП міста

Визначення пріоритетних напрямів малого і середнього

підприємництва міста

Проведення фокус-груп

Узагальнення рекомендацій за результатами роботи із МСП

Розробка рекомендацій щодо посилення

конкурентоспроможності

Pис.1. Модель

формування

програми

посилення конкурентоспроможності

МСП у містах - проект ПРОМІС

Джерело: складено авторами на основі [7]

Уточнимо наведену вище модель за методологією проекту ПРОМІС та запропонуємо покроковий план дій щодо посилення конкурентоспроможності МСП у містах та громадах, що продемонстровано на рис. 2. Зазначену методологію було частково застосовано у частині визначення перспектив розвитку МСП у різних містах.

\begin{tabular}{|c|c|}
\hline Етап 1 & $\begin{array}{l}\text { - Дослідження бізнес-середовища галузі місті } \\
\text { у регіоні }\end{array}$ \\
\hline Етап 2 & • Бенчмаркінг \\
\hline Етап 3 & • Визначення конкурентоспроможності МСП \\
\hline Етап 4 & • Розробка програми посилення МСП \\
\hline
\end{tabular}

Puc.2. Покроковий план дій 3 розробки програми посилення конкурентоспроможності МСП

Джерело: складено авторами

Безумовно, мале і середнє підприємництво створює фундамент для 
стійкого та ефективного розвитку кожної громади та міста. Тому насамперед доцільно визначити пріоритетні напрями або галузі діяльності МСП. Такі галузі варто визначати на основі аналізу статистичних даних, тобто кількості підприємств конкретного напрямку діяльності, а також у процесі діалогу 3 експертами (у випадку Вінниці та Івано-Франківська це були експерти ПРОМІС), з владою, $з$ місцевою бізнес-спільнотою.

Наприклад, у Вінниці до числа пріоритетних напрямів МСП увійшли такі: інформаційні технології, медицина, туризм, соціальне підприємництво, сфера обслуговування, харчова та швейна промисловості. В Івано-Франківську було визначено чотири напрями, зокрема інформаційні технології, сфера гостинності, харчова та деревообробна промисловості.

Об’єктом дослідження виступає саме функціонування МСП зазначених міст у визначених галузях. Мета дослідження полягає у визначенні сильних та слабких сторін МСП міста та розробка рекомендації щодо їх розвитку. Результати подібного дослідження можуть бути використані для розробки Програми посилення конкурентоспроможності МСП, а також застосовані органами місцевого самоврядування та бізнес-асоціаціями для поглиблення взаємодії бізнесу й влади $з$ метою покращення підприємницького клімату в місті.

Дослідження здійснювалось на основі збору, аналізу та обробки первинної та вторинної інформації. Збір первинної інформації передбачає проведення фокус-груп із представниками галузей МСП. Він дав змогу отримати зворотній зв'язок від підприємців, їх бачення і розуміння реалій та перспектив роботи МСП в місті. На основі проведеної дослідницької роботи можна розробити рекомендації щодо посилення МСП міста. Важливим заданням дослідження є розробка пошукових питань, робота із вторинною та первинною інформацією. Первинна інформація зібрана на основі проведених фокус-груп із представниками пріоритетних напрямів МСП. У разі потреби, отримана первинна інформація підлягала повторній перевірці у джерелах вторинної інформації.

Ця модель формування програми посилення конкурентоспроможності малого та середнього підприємництва в конкретному місті складається 3 чотирьох основних етапів. Перший етап передбачає вивчення ділового середовища в місті, що дозволяє отримати характеристики МСП, провідних галузей, проаналізувати та виявити основні тенденції розвитку МСП у місті. Цей етап є дуже важливим, оскільки він підтримує процес ідентифікації найважливіших галузей МСП у місті, а також порівняння поточної ситуації в місті із загальною ситуацією в країні. Другий етап «бенчмаркінгу» спрямований на проведення порівняльного аналізу МСП певного міста з МСП в інших містах-аналогах, де підприємства працюють у подібних умовах ведення бізнесу. Такі міста-аналоги можуть бути розташовані як всередині країни, так i за іiі межами. Третій етап зосереджений на визначенні 
конкурентоспроможності МСП окремого міста. Це, по-перше, аналіз взаємодії 3 ключовими зацікавленими сторонами, а, по-друге, виявлення конкурентних переваг.

Четвертий етап орієнтований на розробку програми посилення конкурентоспроможності МСП у місті. На цьому етапі формується програма посилення конкурентоспроможності МСП окремого міста, заснована на визначенні основних напрямків розвитку.

Розширення запропонованої практики дозволить реально підвищити конкурентоспроможність МСП.

Щодо другого напрямку - розширення експортного потенціалу МСП, то в Україні за останні 5 років реалізовувалась ціла низка проектів започаткованих ЄС, спрямованих на підтримку МСБ. При цьому реалізація експортного потенціалу МСП(МСБ) розглядається не окремо, а в контексті загальних програм підтримки підприємців.

Ініціатива $\mathrm{CC}$ «EU4Business». Проект забезпечує кращий доступ до фінансування, якісні тренінги та можливості вдосконалення знань в сфері експорту до ЄС. Основними напрямками є: пряме або опосередковане фінансування (кредити або гарантії); навчання, тренінги або наставництво; створення можливостей для налагодження зв'язків на ярмарках та у торгових представництвах. Оскільки Україна підписала Угоду про ПВЗВТ з СС, то українські МСП мають додаткову підтримку, яка допомагає їм адаптувати свої процеси та регламенти у відповідності до правил СС для виходу на європейський ринок. Партнерами цієї ініціативи є ЄБРР, Європейський інвестиційний банк (СІБ), Німецький банк розвитку (KfW), ОЕСР, Світовий банк. В межах ініціативи «EU4Business» реалізується ціла низка проектів. Офіційний сайт - https://eu4business.eu/uk/about.

Проект FORBIZ, спрямований на поліпшення бізнес-середовища в Україні, в межах ініціативи EU4Business. В межах проекту створено Платформу ефективного регулювання PRO Biz (https://regulation.gov.ua/). Платформа містить низку інструментів для бізнесу: покрокові інструкції для започаткування власної справи, процедури отримання дозволів, правила розрахунку витрат на регуляторні вимоги тощо, що значно полегшує пошук необхідної інформації.

В межах ініціативи EU4Business в 2019 р. започаткований проект Східне партнерство: Готові до торгівлі - ініціатива "EU4Business" разом із Міжнародним торговельним центром (інвестиційний фокус - експортноорієнтовані МСП). Ініціатива спрямована на посилення торговельних зв'язків iз країнами Східного партнерства - Азербайджаном, Білоруссю, Вірменією, Грузією, Молдовою та Україною. Проект сприяє МСП у виході до нові ринки, зокрема $\mathrm{CC}$, шляхом надання їм допомоги у визначенні та дотриманні стандартів якості відповідно до міжнародних вимог, налагодження зв'язків 3 покупцями в межах виробничо-збутової мережі, а також надання кластерної підтримки. Основні напрямки реалізації: надання торговельної інформації про 
регіон та ЄC на інтернет-порталі; виявлення регуляторних та процедурних перешкод для торгівлі; сприяння вирішенню проблем за допомогою системи онлайн-моніторингу та звітності; розбудова національного потенціалу збору та обробки даних про торгівельні умови для окремих секторів; навчання компаній та організації підтримки бізнесу аналітичного інструментарію аналізу ринків для того, щоб вони змогли виявляти нові можливості в регіоні Східного партнерства та ЄС [8].

Міністерство економічного розвитку i торгівлі України видало огляд «Донорська підтримка у розвитку бізнесу та виході на експорт», де показали можливості підтримки донорів (фондів, урядових та міждержавних організацій), включаючи організації, які надають фінансову підтримку: СБРР, Western NIS Enterprise Fund, Центр зі сприяння імпорту 3 країн, що розвиваються (Kindom of the Netherland), проекти «Сприяння виходу малих $\mathrm{i}$ середніх підприємств плодоовочевого сектору на зовнішні ринки» (International Trade Center), Програма підготовки управлінських кадрів - «Fit For Partnership with Germany», Канадсько-Український проект підтримки торгівлі та інвестицій (CUTIS), Німецька служба старших експертів SES (впровадження новітніх технологій та оптимізація процесів, навчання персоналу та впровадження нових методів роботи), Enterorise Europe Network (формування мережі підприємств-партнерів, доступ до інформації, наукового співробітництва, інноваційної підтримки), Agritrade Ukraine (надання консультацій щодо процедур експорту до СС, проведення тренінгів) тощо [9].

На сайті Міністерства розвитку економіки, торгівлі та сільського господарства $\epsilon$ ресурс «Розвиток малого і середнього підприємництва», який надає інформацію про доступ МСП до державної допомоги, програми підтримки підприємців, корисні сервіси для започаткування та ведення бізнесу тощо [10].Зокрема, серед програм підтримки підприємців зазначені: EU4Business, Програми СС підтримки приватного сектору в Україні - EU SURE (EU Support to Ukraine to Re-launch the Economy), Програма EC "Конкурентоспроможність підприємств малого і середнього бізнесу (COSME) (2014-2020)", Програма для управлінських кадрів сфери підприємництва України (Fit for partnership with Germany), Unlimit Ukraine by ЕВА - Програма розвитку та підтримки малого українського бізнесу, Програма "Fit for Partnership with Germany”, Підтримка малого і середнього підприємництва на міжнародному рівні (міжнародні кредитні лінії), Банківські продукти та програми допомоги малому і середньому підприємництву, Підтримка малого і середнього підприємництва на регіональному рівні [11].

Проте, незважаючи на значну кількість програм підтримки МСП, ситуація 3 розвитком експортної активності МСП не досить оптимістична. Центром економічної стратегії в межах проекту «Побудова мостів в державній політиці: Україна», який реалізується за фінансової підтримки Foundation Open Society Institute в співпраці з OSIFE при Open Society Foundation, було проведене 
дослідження «Як малим та середнім підприємствам України стати національними та глобальними чемпіонами?» (2019), де визначені чинники, що перешкоджають активізації розвитку МСП в цілому та їхній експортній активності. До них віднесли:

- низький рівень довіри в суспільстві, що обумовлює невпевненість стейкхолерів та прагнення поодииноких та групових суб'єктів у започаткуванні бізнесу, впровадженні інновацій або формуванні мереж співпраці;

- слабке верховенство права, що приводить до труднощів у захисті активів або інтелектуальної власності, низької довіри до системи правосуддя, зростання кількості «захоплень» підприємств, монополізації, високого рівня корупції. Аналітики вважають, що «будь-яка ініціатива уряду щодо надання фінансових засобів підтримки МСП може бути сприйнята 3 недовірою 3 боку потенційних отримувачів, оскільки вони можуть не вірити у справедливий розподіл цих коштів» [12, с.33]. Це може бути і причиною низького попиту на державне фінансування та підтримку МСП. Хоча, на наш погляд, значну роль відіграє відсутність інформації та знань, як правильно сформувати запит та ефективно використати можливості, які надаються;

- політична та економічна нестабільність, які обмежують довгострокове (стратегічне) планування підприємств. Основними негативними чинниками вважаються неочікувані зміни у оподаткуванні, регулюванні та зовнішньоторговельній політиці, лобі великого бізнесу. Це також обмежує і впровадження інновацій [12, с.33].

Організація економічного співробітництва та розвитку (OECD) періодично розраховує Індекс економічної політики у сфері МСП в країнах Східного партнерства, оцінюючи реалізацію Свропейського акту про малий бізнес, що є унікальним інструментом порівняльної оцінки, який дозволяє контролювати розробку та здійснення політики в сфері МСП у порівнянні із практиками ЄС (останній огляд 2020 [13]).

Таблиця 2

Результати оцінки України у відповідності з Індексом економічної політики в сфері МСП [13, с.478-479]

\begin{tabular}{|l|c|c|c|}
\hline Напрям & UKR 2016 & UKR 2020 & 3міни (+/-) \\
\hline Інституційно-нормативна база & 2,45 & 3,50 & $+1,05$ \\
\hline Умови діяльності & 3,81 & 3,55 & $-0,26$ \\
\hline $\begin{array}{l}\text { Процедури банкрутства та надання } \\
\text { другого шансу }\end{array}$ & 2,05 & 2,56 & $+0,49$ \\
\hline $\begin{array}{l}\text { Розвиток підприємництва в процесі } \\
\text { навчання та підтримка } \\
\text { підприємницької діяльності жінок }\end{array}$ & 2,26 & 3,98 & $+1,73$ \\
\hline Вміння МСП & 2,56 & 3,19 & $+0,63$ \\
\hline
\end{tabular}




\begin{tabular}{|l|c|c|c|}
\hline Доступ до фінансування & 3,22 & 3,31 & $+0,09$ \\
\hline Державні закупівлі & 2,73 & 3,17 & $+0,44$ \\
\hline Стандарти та технічні нормативи & 4,34 & 3,55 & $-0,79$ \\
\hline Інтернаціоналізація & 1,63 & 2,64 & $+1,01$ \\
\hline Послуги з розвитку бізнесу & 1,84 & 2,90 & $+1,06$ \\
\hline Інновації & 1,86 & 2,28 & $+0,42$ \\
\hline $\begin{array}{l}\text { Використання принципів зеленої } \\
\text { економіки }\end{array}$ & 1,22 & 2,54 & $+1,32$ \\
\hline
\end{tabular}

В цілому, ситуація значно покращилась, але зважаючи на максимальну оцінку в 5 балів, стан економічної політики України в сфері МСП вимагає посилення уваги та результативності.

В контексті теми нашого дослідження можливості інтернаціоналізації МСП покращилися, що відмічалося нами раніше під час аналізу зміни місці України в Doing Business report. Проте, серед основних експортних бар'єрів українські підприємці визначають непередбачувану зовнішньоторговельну політику України, недостатній розвиток транспортної інфраструктури, високий рівень бюрократії під час проходження митних процедур (створена система єдиного вікна не забезпечує очікуваної ефективності), велика кількість дозвільних документів. Відсутній системний підхід щодо формування зв'язків між МСП та великими вітчизняними чи іноземними інвесторами у ланцюгах постачання. А розвитку електронної комерції перешкоджає недостатня поінформованість МСП та обмеженість послуг щодо навчання та підтримки в цій сфері [13, с.500-501]. А зважаючи на виклики, що приніс covid-19, дестабілізаційні впливи на дану сферу посилюються.

Висновки. Конкурентоспроможність МСП обумовлена насамперед потенціалом, який закладений у МСП і багато в чому залежить від залученості різних груп зацікавлених сторін. Тому був запропонований стратегічний підхід формування програми посилення конкурентоспроможності МСП у конкретному місті, що складається з 4-х етапів, які передбачають аналіз бізнессередовища МСП, бенчмаркінг, визначення конкурентоспроможності МСП та розробку самої програми. Така програма може доповнюватися напрямками діяльності щодо забезпечення підтримки експортного потенціалу МСП на центральному рівні. Поєднання місцевого та держаного рівня підтримки якраз i може сьогодні дати синергічний ефект в ускладнених covid-19 умовах.

\section{Лimepamypa:}

1. Горюнов Д., Кравченко О., Вдовенко Ю., Денисюк Г. Огляд МСП в Україні 2018/2019: Фокус на європейській інтеграції. Київ : 2020. URL: https://drive.google.com/file/d/1I2ckLnFpxcbePvy_ymQ1JMi5Wci5RKxP/view (дата звернення: 27.08.2021). 
2. Українське суспільство. Двадцять років незалежності. Незалежний моніторинг : у 2 т. / за ред. Д. філософ. н. Є.І. Головахи, д. соц. н. М.О. Шульги. К. : Інститут соціології НАН України, 2011. Т.2. 480 с.

3. Бураковський I., Крініцин О., Сологуб I. Політика сприяння експорту МСП в Укpaїні. Київ, 2015. 36 p. URL: http://www.ier.com.ua/files//publications/Policy_papers/ IER/2016/LEV/Krinitsyn_SME_Export_Promotion.pdf ; Покришка Д. С. Розвиток експортного потенціалу малих і середніх підприємств як чинник компенсації втрат України на традиційних зовнішніх ринках. Економічний вісник НТУУ «КПI». 2018. № 15. C. 72-81. URL: https://ela.kpi.ua/handle/123456789/26383 ; Панцир С. Когут А. Політика підтримки МСБ: доступ до фінансово-кредитних ресурсів (Policy Paper). Київ, 2015. 17 с. URL: http://euinfocenter.rada.gov.ua/uploads/documents/28824.pdf (дата звернення: 03.10.2021)

4. Зовнішня торгівля України. Статистичний збірник. Діяльність суб'єктів господарювання Статистичний збірник / Державна служба статистики України. URL: http://www.ukrstat.gov.ua/ (дата звернення: 25.06.2021)

5. Експорт товарів суб'єктами господарювання за кількістю найманих працівників за видами економічної діяльності. URL: http://www.ukrstat.gov.ua/operativ/operativ2018/zd/et_ knp_reg/arh_et_knp_u.html; Показники діяльності великих, середніх, малих та мікропідприємств. URL: http://www.ukrstat.gov.ua/ (дата звернення: 15.10.2021)

6. Індекс конкурентоспроможності міст 2019/2020. URL: http://www.ier.com.ua/files/ Projects/2020/MCI/reports1/MCI_2019-2020_Part\%201_UKR.pdf (дата звернення: 25.06.2021).

7. Partnership for Local Economic Development and Democratic Governance (PLEDDG) : веб-сайт. URL: http://pleddg.org.ua/en (дата звернення: 25.06.2021).

8. International Trade Centre. Eastern Partnership Trade Helpdesk. URL: https://www.intracen.org/EaP/ (дата звернення: 18.10.2021)

9. Донорська підтримка у розвитку бізнесу та виході на експорт. Міністерство економічного розвитку i торгівлі України. 22 c. URL: https://epo.org.ua/wpcontent/uploads/PDF/Donors.pdf (дата звернення: 18.10.2021)

10. Розвиток малого і середнього підприємництва. Міністерство розвитку економіки, торгівлі та сільського господарства України. Офіційний сайт. URL: https://www.me.gov.ua/Tags/DocumentsByTag?lang=uk-UA\&id=295cacd3-0b67-4ec8-88c1c998a482f50d\&tag=RozvitokMalogoISerednogoPidprimnitstva (дата звернення: 18.10.2021)

11. Програми підтримки підприємців. Міністерство розвитку економіки, торгівлі та сільського господарства України. Офіційний сайт. URL: https://www.me.gov.ua/Documents/ List?lang=uk-UA\&tag=ProgramiPidtrimkiPidprimtsiv\&pageNumber=1 (дата звернення: 18.10.2021)

12. Як малим та середнім підприємствам України стати національними та глобальними чемпіонами? Аналітична записка. Центр економічної стратегії. К., 2019. 48 с. URL: https://ces.org.ua/wp-content/uploads/2019/09/\%D0\%A6\%D0\%95\%D0\%A1-final-UA.pdf (дата звернення: 24.10.2021)

13. SME Poiicy Index: Easten Partner Countries 2020 - Assessing the Implementation of the Small Business Act for Europe. EBRD/ETF/European Union/OECD 2020. OECD publishing, Paris. 526 p. URL: https://www.oecd-ilibrary.org/docserver/8b45614b-en.pdf?expires= 1596481740\&id=id\&accname=guest $\&$ checksum =DA0B687C8C768EE894EE7FA56A8F7731 (дата звернення: 24.10.2021)

\section{References:}

1. Horiunov D., Kravchenko O., Vdovenko Yu., Denysiuk H. (2020) Ohliad MSP v Ukraini 2018/2019: Fokus na yevropeiskii intehratsii [SME Review in Ukraine 2018/2019: Focus on European integration] Kyiv. : 2020. URL: https://drive.google.com/file/d/1I2ckLnFpxcbePvy_ ymQ1JMi5Wci5RKxP/view (accessed 27 August 2021) [in Ukrainian]. 
2. Ukrainske suspilstvo. Dvadtsiat rokiv nezalezhnosti. Nezalezhnyi monitorynh (2011) [Ukrainian society. Twenty years of independence. Independent monitoring] in 2 volumes / ed. d. philosopher. N. Ye.I. Golovahi, d. Soc. N. M.O. Shulgi. K.: Institute of Sociology of the National Academy of Sciences of Ukraine. Vol.2. 480 p. [in Ukrainian].

3. Burakovskyi I., Krinitsyn O., Solohub I. (2015) Polityka spryiannia eksportu MSP v Ukraini [SME export promotion policy in Ukraine] URL: http://www.ier.com.ua/files// publications/Policy_papers/IER/2016/LEV/Krinitsyn_SME_Export_Promotion.pdf ; Pokryshka D. S. (2018) Rozvytok eksportnoho potentsialu malykh i serednikh pidpryiemstv yak chynnyk kompensatsii vtrat Ukrainy na tradytsiinykh zovnishnikh rynkakh [Development of export potential of small and medium enterprises as a factor of compensation of losses of Ukraine in traditional foreign markets] Economic Bulletin of NTUU "KPI". 2018. № 15. C. 72-81. URL: https://ela.kpi.ua/handle/123456789/26383 ; Pantsyr S. Kohut A. (2015) Polityka pidtrymky MSB: dostup do finansovo-kredytnykh resursiv (Policy Paper) [SME Support Policy: Access to Financial and Credit Resources (Policy Paper)]. Kyiv. 17 p. URL: http://euinfocenter.rada.gov.ua/ uploads/documents/28824.pdf (accessed 03 October 2021). [in Ukrainian].

4. Zovnishnia torhivlia Ukrainy [Ukraine's foreign trade] Statistical collection. Diialnist subiektiv hospodariuvannia [Activities of business entities] Statistical Collection / State Statistics Service of Ukraine. URL: http://www.ukrstat.gov.ua/ (accessed 25 June 2021). [in Ukrainian].

5. Eksport tovariv subiektamy hospodariuvannia za kilkistiu naimanykh pratsivnykiv za vydamy ekonomichnoi diialnosti [Exports of goods by economic entities by number of employees by type of economic activity]. URL: http://www.ukrstat.gov.ua/operativ/operativ2018/zd/ et_knp_reg/arh_et_knp_u.html; Pokaznyky diialnosti velykykh, serednikh, malykh ta mikropidpryiemstv [Performance indicators of large, medium, small and micro enterprises]. URL: http://www.ukrstat.gov.ua/ (accessed 25 June 2021). [in Ukrainian].

6. Indeks konkurentospromozhnosti mist 2019/2020 [Cities Competitiveness Index 2019/2020]. URL: http://www.ier.com.ua/files/Projects/2020/MCI/reports1/MCI_2019-2020_ Part\%201_UKR.pdf (accessed 25 June 2021). [in Ukrainian].

7. Partnership for Local Economic Development and Democratic Governance (PLEDDG) : website. URL: http://pleddg.org.ua/en (accessed 25 June 2021). [in English]

8. International Trade Centre. Eastern Partnership Trade Helpdesk. URL: https://www.intracen.org/EaP/ (accessed 18 October 2021). [in English].

9. Donorska pidtrymka u rozvytku biznesu ta vykhodi na eksport [Donor support in business development and export.]. Ministry of Economic Development and Trade of Ukraine. 22 p. URL: https://epo.org.ua/wp-content/uploads/PDF/Donors.pdf (accessed 18 October 2021). [in Ukrainian].

10. Rozvytok maloho i serednoho pidpryiemnytstva [Development of small and medium business]. Ministry of Economic Development, Trade and Agriculture of Ukraine : website. URL: https://www.me.gov.ua/Tags/DocumentsByTag?lang=uk-UA\&id=295cacd3-0b67-4ec8-88c1-

c998a482f50d\&tag=RozvitokMalogoISerednogoPidprimnitstva (accessed 18 October 2021). [in Ukrainian].

11. Prohramy pidtrymky pidpryiemtsiv [Entrepreneur support programs]. Ministry of Economic Development, Trade and Agriculture of Ukraine : website. URL: https://www.me.gov.ua/Documents/List?lang=uk-UA\&tag=ProgramiPidtrimkiPidprimtsiv\&pageNumber=1 (accessed 18 October 2021). [in Ukrainian].

12. Yak malym ta serednim pidpryiemstvam Ukrainy staty natsionalnymy ta hlobalnymy chempionamy? [How can small and medium enterprises of Ukraine become national and global champions?] Analytical note. Center for Economic Strategy. Kyiv. 2019. 48 p. URL: https://ces.org.ua/wp-content/uploads/2019/09/\%D0\%A6\%D0\%95\%D0\%A1-final-UA.pdf (accessed 24 October 2021). [in Ukrainian]. 
13. SME Poiicy Index: Easten Partner Countries 2020 - Assessing the Implementation of the Small Business Act for Europe. EBRD/ETF/European Union/OECD 2020. OECD publishing, Paris. 526 p. URL: https://www.oecd-ilibrary.org/docserver/8b45614b-en.pdf?expires= 1596481740\& id=id\&accname=guest\&checksum=DA0B687C8C768EE894EE7FA56A8F7731 (accessed 24 October 2021). [in English]. 